\title{
MINIMALISIR KETAKUTAN MASYARAKAT MELALUI KEGIATAN SOSIALISASI DAN EDUKASI PENTINGNYA VAKSINASI COVID-19
}

\author{
Rahma Ari Widihastuti ${ }^{1}$, Ani Maulani ${ }^{2}$, Wahyuni Lia Wulandari ${ }^{3}$, Putri Wulandari ${ }^{4}$, \\ Muhlis Safi' ${ }^{5}$, Ayu Lestari ${ }^{6}$ \\ Fakultas Hukum, Fakultas Ekonomi,Universitas Negeri Semarang \\ *e-mail: animaulani@students.unnes.ac.id, ayulestari@students.unnes.ac.id
}

\begin{abstract}
Abstrak
Covid-19 telah menyebar di Indonesia sejak 2020 lalu dan telah menimbulkan korban jiwa, serta kerugian material yang semakin besar. Sehingga berimplikasi pada aspek sosial, ekonomi, dan kesejahteraan masyarakat. Pemerintah telah melakukan beberapa kebijakan seperti Pembatasan Sosial Berskala Besar (PSBB) namun tidak kunjung mendapatkan titik terang akan berakhirnya virus ini. Hingga pada akhirnya diadakan vaksinasi Covid-19 namun justru mendapatkan beberapa tanggapan pro dan kontra dari masyarakat, bahkan tidak sedikit pula yang takut karena beberapa informasi hoax yang beredar. Kegiatan sosialisasi dan edukasi seputar Covid-19 sangat diperlukan dalam keadaan seperti ini. Dalam kegiatan sosialisasi, banyak masyarakat yang antusias dan merasa terbantu akan informasi-informasi yang disampaikan, namun ada pula masyarakat yang masih menolak untuk dilakukan vaksinasi Covid-19 dan masih mempercayai bahwa Covid-19 merupakan konspirasi.
\end{abstract}

Kata Kunci: Covid-19, Masyarakat, Pemerintah, Vaksin

\begin{abstract}
Covid-19 has spread in Indonesia since 2020 and has caused greater casualties and material losses. So that it has implications for social, economic, and community welfare aspects. The government has implemented several policies such as Large-Scale Social Restrictions but the virus still does not end. Until finally the Covid-19 vaccination was held, but instead received several pro and con responses from the public, not even a few were afraid because of some hoax information circulating. Socialization and education activities about Covid-19 are very much needed in these circumstances. In socialization activities, many people were enthusiastic and felt helped by the information conveyed, but there were also people who still refused to be vaccinated against Covid-19 and still believed that Covid-19 was a conspiracy.
\end{abstract}

\section{Keywords: Covid-19, Society, Government, Vaccines}

\section{PENDAHULUAN}

Pada bulan Juli 2021, Indonesia mencapai puncak tertinggi harian penyebaran virus Covid-19 setelah Brazil dan India (Woldometer, 2020). Jumlah total penyebaran tersebut mencapai 2.379.397 jiwa. Pemerintah Indonesia mencatat 5 provinsi dengan kejadian Covid19 tertinggi adalah DKI Jakarta, Jawa Barat, Jawa Tengah, Jawa Timur, Sulawesi Selatan, dan Kalimantan Timur (Gugus Tugas Percepatan Penanganan Covid-19, 2020). Temuan kasus Covid-19 di Kabupaten Sragen hingga bulan Juli 2021 memecahkan rekor tertinggi yakni bertambah 271 kasus dengan angka kematian 21 orang dalam sehari. Satu tahun sudah 
bencana wabah Covid-19 menghantui masyarakat. Wabah yang dimulai dari Wuhan Cina hingga berlanjut ke berbagai penjuru dunia, termasuk Indonesia (Nurdiana, Wariah, \& Yanti, 2020; Shi et al., 2020; Zhai et al., 2020).

Di Indonesia dampak pandemi Covid-19 terus menunjukkan peningkatan dari waktu ke waktu bahkan menimbulkan banyak korban jiwa. Kerugian material semakin besar, sehingga berimplikasi pada aspek sosial, ekonomi, dan kesejahteraan masyarakat. Di samping itu dampak ke Perekonomian Negara sangat signifikan, diantaranya yaitu perlambatan pertumbuhan ekonomi nasional, penurunan penerimaan negara, dan peningkatan belanja negara dan pembiayaan. Tidak hanya itu, pandemi Covid-19 juga berdampak pada memburuknya sistem keuangan yang ditunjukkan dengan penurunan berbagai aktivitas ekonomi domestik. Masyarakat dituntut untuk berdamai dengan virus Corona. Pemerintah pun telah melakukan beragam upaya untuk menghentikan penyebaran Covid-19, salah satunya adalah kebijakan Pembatasan Sosial Berskala Besar (PSBB) yaitu dengan menutup jalur transportasi udara, darat, dan laut, menghentikan sementara aktivitas pembelajaran serta bekerja secara tatap muka, menutup sementara sarana hiburan, sarana ibadah serta sarana masyarakat lainnya (Gugus Tugas Percepatan Penanganan Covid-19, 2020). Berbagai upaya dan strategi yang telah dilakukan tersebut tidak serta merta menghentikan penyebaran Covid19. Hingga akhirnya pada tanggal 13 Januari 2021, Presiden Joko Widodo menjalani vaksin perdana di Istana Negara yang sekaligus menjadi tanda dimulainya vaksinasi massal Covid19 di Indonesia.

Di tengah merebaknya rencana pemerintah untuk pemberian vaksinasi Covid-19 secara massal, nampaknya menuai berbagai tanggapan pro dan kontra dari kalangan masyarakat. Pro dan kontra bermunculan baik kalangan muda maupun tua, remaja maupun dewasa. Banyak masyarakat yang berbondong-bondong untuk melakukan vaksinasi, namun banyak pula yang menolak untuk diberikan suntik vaksin Covid-19. Seperti halnya masyarakat di Desa Hadiluwih khususnya para remaja. Ada beberapa hal yang membuat masyarakat ragu untuk diberi suntikan vaksin Covid-19. Salah satunya adalah Kejadian Ikutan Pasca-Imunisasi (KIPI). Banyak sekali berita negatif tentang adanya dampak vaksin Covid-19. Hampir semua masyarakat terpengaruh dengan adanya berita negatif ( hoax) tersebut, beberapa diantaranya: terjadinya kelumpuhan, kebutaan, pembekuan darah, bahkan meninggalnya seseorang setelah disuntikan vaksin Covid-19 ke tubuhnya. Berita tersebut menyebar dengan cepat ke masyarakat Indonesia termasuk di Desa Hadiluwih. Selain aspek medis, masih terdapat alasan dari aspek agama dan politik. Beberapa masyarakat masih menganggap bahwa vaksin 
Covid-19 adalah bisnis dan banyak kepentingan di dalamnya. Anggapan bahwa berita media terkesan menakut-nakuti dan justru malah mempercayai teori konspirasi juga menjadi penyebab masyarakat sulit untuk diberi vaksin Covid-19. Selain itu, tidak sedikit remaja yang menyamakan Covid-19 dengan masuk angin biasa, mereka menganggap fisik yang masih muda tidak akan mudah terkena Covid-19.

Berdasarkan sikap masyarakat yang menolak vaksinasi Covid-19, sebagai upaya untuk meluruskan pemahaman masyarakat tentang vaksin Covid-19, maka pengabdi bekerja sama dengan Kader dan Bidan Desa Hadiluwih melakukan kegiatan sosialisasi dan edukasi seputar Covid-19. Kegiatan tersebut diusulkan dengan harapan agar program vaksinasi massal dapat tercapai secara optimal. Dengan adanya kegiatan ini diharapkan masyarakat Desa Hadiluwih mengetahui pentingnya vaksin Covid-19 sebagai salah satu langkah nyata dan efektif menekan bahkan menghentikan penyebaran virus Covid-19, dan pada akhirnya menjadi bersedia untuk diberikan vaksin Covid-19.

\section{METODE PELAKSANAAN}

Kegiatan sosialisasi dan edukasi pentingnya vaksinasi Covid-19 dilakukan kepada masyarakat Dukuh Kedungdowo RT 02, Desa Hadiluwih, Kecamatan Sumberlawang, Kabupaten Sragen pada hari Sabtu, 4 September 2021. Kegiatan ini memiliki latar belakang kurangnya kesadaran, pemahaman, dan antusiasme mengenai program vaksinasi Covid-19. Pelaksanaan melalui 4 tahapan, yaitu:

1) Observasi tempat, situasi dan kelompok sasaran guna mendapatkan informasi untuk menganalisis masalah masyarakat Dukuh Kedungdowo RT 02, Desa Hadiluwih, Kecamatan Sumberlawang, Kabupaten Sragen.

2) Persiapan sarana dan prasarana meliputi poster yang berisi pengertian, efek samping, dan manfaat vaksin Covid-19.

3) Pelaksanaan kegiatan inti program sosialisasi dan edukasi pentingnya vaksinasi Covid-19 dilakukan dengan metode ceramah. Salah satu strategi agar penjelasan tersampaikan dengan maksimal, maka sarana penunjang kegiatan dilakukan dengan menggunakan media poster yang dibagikan kepada masyarakat Dukuh Kedungdowo RT 02, Desa Hadiluwih, Kecamatan Sumberlawang, Kabupaten Sragen. Adapun teknis pelaksanaan dilakukan secara tatap muka dengan dua acara. Pertama, mengumpulkan remaja pada suatu tempat dan tentunya sesuai dengan protokol kesehatan. Kedua, 
melakukan kegiatan sosialisasi dengan cara door to door mendatangi setiap rumah masyarakat. Selain sosialisasi langsung. Kegiatan sosialisasi dan edukasi juga dilakukan melalui aplikasi Whatsapp. Hal ini dilakukan mengingat terbatasnya waktu dan prosedur kesehatan yang ketat, sehingga sosialisasi tidak bisa maksimal jika hanya dilakukan dengan cara luring.

4) Kegiatan terakhir evaluasi proses dan hasil dari pelaksanaan sosialisasi. Pengabdi melakukan pemantauan setelah pemberian sosialisasi kepada remaja Dukuh Kedungdowo RT 02, Desa Hadiluwih, Kecamatan Sumberlawang, Kabupaten Sragen. Hasil akhir dari kegiatan ini diharapkan masyarakat menjadi menghendaki dengan suka rela melakukan vaksin Covid19.

\section{HASIL DAN PEMBAHASAN}

Menurut Direktorat Surveilans dan Karantina Kesehatan dan Ditjen P2P Kementrian Kesehatan (2020) vaksin merupakan suatu senyawa (biologis) yang diberikan kepada seseorang dengan maksud untuk menghasilkan kekebalan terhadap suatu penyakit dengan cara menstimulasi produksi antibodi. Umumnya vaksin mengandung suatu zat yang mewakili kuman penyebab penyakit, seringkali dibuat dari kuman yang dimatikan atau dilemahkan. Zat tersebut menstimulasi sistem kekebalan tubuh untuk mengenalinya sebagai zat asing, lalu terpincu untuk mengeliminasikannya, dan membentuk memori, sehingga sistem kekebalan tubuh dapat dengan mudah menangkal kuman jika suatu saat dikemudian hari kuman tersebut menginfeksi tubuh.

Vaksin adalah produk biologi yang berisi antigen yang bila diberikan kepada seseorang akan menimbulkan kekebalan spesifik secara aktif terhadap penyakit tertentu (www.covid19.go.id Januari 2020).

Mengingat pentingnya keberadaan vaksin Covid-19, negara-negara di dunia, termasuk Indonesia menjadikan pemberian vaksin Covid-19 sebagai prioritas dalam penanggulangan pandemi Covid-19. Selama tahun 2020 terdapat beberapa negara yang telah melakukan vaksinasi, seperti Inggris, Amerika Serikat, dan Kanada. Pemerintah akan terus mengikuti perkembangan vaksinasi yang telah dilakukan oleh berbagai negara sebagai bahan masukan untuk program vaksinasi nasional. Di Indonesia, Pemerintah mengambil kebijakan yang dituangkan dalam bentuk program pengadaan vaksin dan pemberian vaksinasi Covid19 sebagai bagian dari Penanganan Covid-19 dan Pemulihan Ekonomi Nasional. Pemberian 
vaksin tersebut secara umum bertujuan untuk mengurangi transmisi atau penularan Covid-19, menurunkan angka kesakitan dan kematian akibat Covid-19, mencapai kekebalan kelompok di masyarakat (herd immunity), selain itu juga melindungi masyarakat dari Covid-19 agar tetap produktif secara sosial dan ekonomi. Kebutuhan akan vaksin cukup besar mengingat banyaknya negara-negara di dunia yang juga membutuhkan vaksin Covid-19, maka pemerintah Indonesia menempuh beberapa cara sekaligus, yakni melalui 3 cara untuk memenuhi kebutuhan dalam negeri. Pertama, mengembangkan vaksin Covid-19 Merah Putih secara mandiri di dalam negeri, kedua melakukan pembelian vaksin dari luar negeri, dan yang ketiga melakukan kerja sama dengan lembaga internasional.

Berdasarkan kegiatan sosialisasi dan edukasi pentingnya vaksin Covid-19 yang dilakukan oleh pengabdi kepada masyarakat Dukuh Kedungdowo RT 02, Desa Hadiluwih, Kecamatan Sumberlawang, Kabupaten Sragen, kegiatan pertama yang dilakukan adalah pembuatan poster untuk sarana penunjang ketika sosialisasi. Setelah pembuatan poster selesai dan sesuai dengan keadaan masyarakat, kemudian poster dicetak melebihi jumlah rumah dalam Dukuh tersebut. Hal ini dilakukan dengan tujuan selain cara door to door, sisa poster ditempel di tempat-tempat strategis seperti mading balai desa, perempatan yang dirasa strategis, tembok di warung sekitar, dan beberapa lokasi lainnya.

Selanjutnya pada tanggal 4 September 2021 dilakukan kegiatan sosialisasi dan edukasi pentingnya vaksin Covid-19. Kegiatan pelaksanaan dimulai dari:

1. Memperkenalkan diri dan menyampaikan maksud dan tujuan dari sosialisasi.

2. Menyampaikan sosialisasi dengan media poster yang diberikan kapada masyarakat Dukuh Kedungdowo RT 02, Desa Hadiluwih, Kecamatan Sumberlawang, Kabupaten Sragen. Poster tersebut berisi pengertian, efek samping, dan manfaat vaksin covid-19.

Kegiatan sosialisasi dan edukasi pentingnya vaksinasi Covid-19 dilakukan dengan metode ceramah dan dibantu dengan media poster. Pengabdi memberikan penjelasan tentang beberapa informasi mengenai vaksin covid-19 yang diharapkan dapat menambah pengetahuan dan meluruskan pemahaman yang keliru mengenai vaksinasi dalam kehidupan sehari-hari di kalangan masyarakat. Sebagaimana sasaran kegiatan yaitu masyarakat Dukuh Kedungdowo RT 02, Desa Hadiluwih, Kecamatan Sumberlawang, Kabupaten Sragen secara menyeluruh,yaitu total 260 jiwa, sehingga teknis pelaksanaan kegiatan dilakukan dengan dua cara, yaitu pertama, mengumpulkan remaja di kediaman pengabdi dan tentunya sesuai dengan protokol kesehatan. Kegiatan ini selain lebih efisien dan dapat berdiskusi dengan 
remaja sekitar, juga dapat menghemat waktu dalam sosialisasi. Total peserta remaja yang hadir sebanyak 7 orang yang berkisar dari usia 13 tahun hingga 22 tahun. Teknis pelaksanaan kegiatan yang kedua, melakukan kegiatan sosialisasi dengan cara door to door mendatangi 30 rumah warga. Dikarenakan telah kita ketahui bahwa ikatan sosial masyarakat pedesaan relatif tinggi, sehingga ketika ada salah satu keluarga mendapat hal baru mereka akan cepat berbagi. Tingkat kepercayaan atas informasi dari luar muncul jika melibatkan yang berasal dari keluarga. Adanya kepercayaan bagi anggota keluarga yang telah mampu untuk membantu keluarganya belajar akan merasa termotivasi belajar sendiri, karena tutor berasal dari lingkungan keluarga. Dengan hal ini diharapkan sosialisasi yang dilakukan dengan cara door to door tersebut juga mampu memberikan informasi dari satu keluarga ke keluarga lain . Selain sosialisasi secara langsung, kegiatan sosialisasi dan edukasi juga dilakukan melalui aplikasi Whatsapp group warga Dukuh Kedungdowo RT 02. Hal ini dilakukan mengingat terbatasnya waktu dan adanya prosedur kesehatan yang ketat, sehingga pengabdi rasa kegiatan dengan tatap muka kurang maksimal.

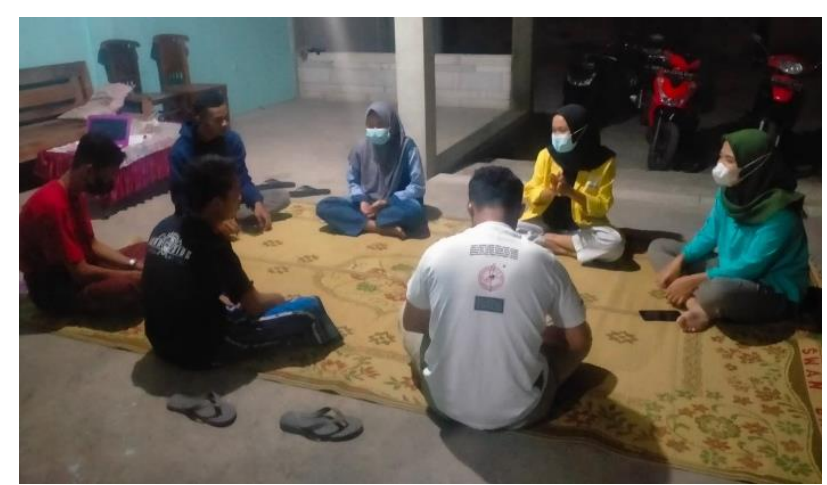

Gambar 1. Sosialisasi pentingnya vaksin Covid-19 kepada remaja.

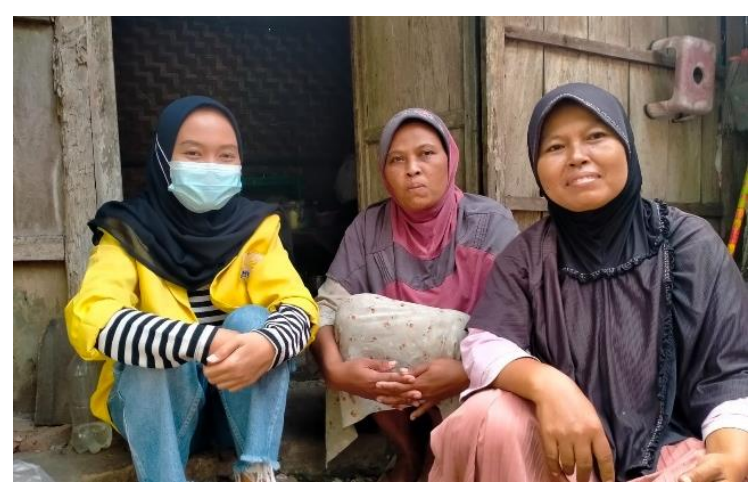

Gambar 2. Sosialisasi pentingnya vaksin Covid-19 kepada masyarakat dengan cara door to door.

Kegiatan sosialisasi yang dilakukan oleh pengabdi tidak luput dari beberapa faktor pendukung dan kendala yang dihadapi. Faktor pendukung dari kegiatan tersebut antara lain: 1. Mayoritas peserta sosialisasi antusias dan memiliki kemauan untuk mendapatkan informasi mengenai pentingnya vaksinasi covid-19 di masa pandemi.

2. Kegiatan sosialisasi didukung penuh oleh perangkat desa baik secara langsung maupun tidak langsung. Pihak perangkat desa memperkenankan pengabdi untuk menyebarkan sosialisasi melalui Whatsapp group RT 02 serta turut serta menanggapi pesan yang disampaikan oleh pengabdi. 
Kendala dalam kegiatan sosialisasi antara lain:

1. Terdapat 3 orang partisipan yang menolak dan masih mempercayai bahwa Covid-19 merupakan konspirasi dan permainan kaum kelas elit belaka.

2. Dari total 30 rumah yang pengabdi datangi, $85 \%$ telah mematuhi protokol kesehatan seperti terdapat tempat cuci tangan dan sabun didepan rumahnya. Namun masih banyak masyarakat tidak menggunakan masker khususnya para orang tua karena menganggap bahwa sosialisasi yang pengabdi lakukan bukan merupakan kegiatan resmi dan menganggap bahwa covid-19 sudah tidak ada. Anggapan ini disimpulkan sendiri dari penurunan angka penderita covid-19 di lingkungan sekitar.

3. Keterbatasan kemampuan pengabdi selaku penyelenggara untuk menjawab beberapa pertanyaan oleh partisipan.

Sosialisasi seputar vaksin sangatlah penting bagi masyarakat yang masih awam akan informasi, masyarakat merasa terbantu akan adanya sosialisasi ini dan diharapkan perlahan menjadi menghendaki untuk diberikan vaksin Covid-19.

\section{KESIMPULAN}

Berdasarkan pengabdian yang telah pengabdi laksanakan, dapat disimpulkan sebagai berikut:

1. Dari total warga Dukuh Kedungdowo RT 02 sebanyak 260 jiwa, pengabdi mendatangi 30 rumah warga untuk dilakukan sosialisasi. Mayoritas masyarakat Dukuh Kedungdowo RT 02, Desa Hadiluwih, Kecamatan Sumberlawang, Kabupaten Sragen antusias dan merasa terbantu akan adanya sosialisasi dan edukasi pentingnya vaksin covid-19 ini, namun terdapat 3 partisipan yang masih menolak untuk divaksin dan mempercayai bahwa covid-19 merupakan konspirasi dan permainan kaum kelas elit belaka.

2. Evaluasi dalam kegiatan ini akan dilakukan pemantauan masyarakat dalam kegiatan vaksinasi massal di Kantor Balai Desa Hadiluwih. Pemantauan dilakukan untuk mengukur seberapa banyak masyarakat yang menghendaki untuk dilakukan vaksin Covid-19, terkhusus warga Dukuh Kedungdowo RT 02, Desa Hadiluwih, Kecamatan Sumberlawang, Kabupaten Sragen setelah dilakukan kegiatan sosialisasi pentingnya vaksin covid-19. 


\section{DAFTAR PUSTAKA}

Andriani, Bella Putri, Dianto, Dila Monica, Muhammad Jordan, Muhammad Risky, Poppu Arsika, Rafita, Rizki Nursapitri \& Salmawati. 2021. Pentingnya Pengenalan Vaksin di Masa Pandemi Covid-19 Desa Ibul Kecamatan Simpang Teritip. Jurnal Abdimas Bina Bangsa Vol. 2 Nomor 1.

Arswendi, Shella Yulima, Nurdiana, Diana, Armin Widayanto, Ega, Haviz \& Yoga. 2020. Analisis Penerapan 5M Dan Vaksinasi Dalam Meningkatkan Kesadaran Diri Masyarakat Saat Pandemi Covid-19 Di Desa Limbung. Jurnal Abdimas Bina Bangsa Vol. 02 No. 01.

Buku Saku \#Infovaksin, Komite Penanganan COVID-19 dan Pemulihan Ekonomi Nasional, Satgas Penanganan COVID-19.

https://anggaran.kemenkeu.go.id/in/post/penanggulangan-pandemi-covid-19-melaluiprogram-pengadaan-vaksin-dan-pelaksanaan-vaksinasi-covid-19

Iris Rengganis. 2014. Vaksinasi Pada Usia Lanjut. Jurnal Penyakit Dalam Indonesia Vol. 4 No. 4.

Kementerian Kesehatan. 2020. Protokol Kesehatan Bagi Masyarakat di Tempat dan Fasilitas Umum dalam Rangka Pencegahan dan Pengendalian Corona Virus Disease 2019 (Covid-19). Jakarta: Kementerian Kesehatan Republik Indonesia.

Nurdiana, Astri, Rina Marlina \& Weni Adityasning. 2021. Berantas Hoax Seputar Vaksin Covid19 Melalui Kegiatan Edukasi dan Sosialisasi Vaksin Covid-19. Jurnal Abdimas Umtas Vol. 4 No. 1.

Wahyudi ER, Dwimartutie N, Yasmine E. 2017. Vaksinasi pada usia lanjut. Dalam: Djauzi S, Rengganis I, Sundoro J, Koesnoe S, Soegiarto G, Maria S, editor. Pedoman imunisasi pada orang dewasa 2017. Jakarta: Interna Publishing.

Wibawa, T. 2021. COVID-19 vaccine research and development: ethical issues. Tropical Medicine and International Health. https://doi.org/10.1111/tmi.13503 